MUSEUM L ECTURES.

COMPARATIVE ANATOMY.

\begin{tabular}{|c|c|c|c|}
\hline 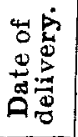 & $\begin{array}{l}\text { Name of } \\
\text { lecturer. }\end{array}$ & 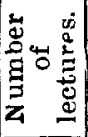 & Title of lecture. \\
\hline 1814 & $\begin{array}{l}\text { Astley Paston } \\
\text { Cooper. }\end{array}$ & 15 & Comparative Anatomy. \\
\hline 1815 & $\begin{array}{l}\text { Astley Paston } \\
\text { Cooper. }\end{array}$ & 15 & Comparative Anatomy. \\
\hline 1816 & $\begin{array}{l}\text { William } \\
\text { Lawrence. }\end{array}$ & 15 & $\begin{array}{l}\text { An Introduction to Comparative } \\
\text { Anatomy and Physiology. }\end{array}$ \\
\hline 1822 & Everal & 15 & Comparative Anatomy. \\
\hline & Herbert Mayo. & 15 & $\begin{array}{l}\text { Anatomy and Physiolngy of the Nervous } \\
\text { System in the Different Classes of } \\
\text { Animals. } \\
\text { Development of the Brain in Man and } \\
\text { Functions of the Cerebral Nerves. }\end{array}$ \\
\hline 1830 & Herbert Mayo. & 15 & $\begin{array}{l}\text { Anatomy and Physiology of the Organs } \\
\text { of Sense in the Different Classes of } \\
\text { Animals. } \\
\text { Physiology of Sleep, Volition, Muscular } \\
\text { Action, Respiration, and Vocal Organs. }\end{array}$ \\
\hline 1832 & Charles Bell. & 15 & $\begin{array}{l}\text { On Life and Organisation; on the } \\
\text { Skeleton; and on the Physiology of the } \\
\text { Nervous System. }\end{array}$ \\
\hline 1833 & Charles Bell. & 15 & $\begin{array}{l}\text { On the Prospective Design indicated by } \\
\text { the Adaptation of the Organs of } \\
\text { Support, or the Hard Parts, of the } \\
\text { Different Classes of Animals to their } \\
\text { Habits, and to the Circumstances in } \\
\text { which they are Placed. } \\
\text { The Teeth in the Different Classes of } \\
\text { Animals, and the Different Kinds of } \\
\text { Articulation of the Bones, and the } \\
\text { Arrangement of the Muscles similarly } \\
\text { considered } \\
\text { Physiology of the Nervous System as } \\
\text { connected with the Anatomy of Ex- } \\
\text { pression. }\end{array}$ \\
\hline & & & SURGERY. \\
\hline 1819 & James Wilson. & 9 & $\begin{array}{l}\text { Lectures on the Blood and on the } \\
\text { Anatomy, Physiology, and Surgical } \\
\text { Pathology of the Vascular System of } \\
\text { the Human Body. }\end{array}$ \\
\hline 1820 & James Wilson. & 9 & $\begin{array}{l}\text { Lectures on the Structure and Physio- } \\
\text { logy of the Parts composing the } \\
\text { Skeleton and on the Diseases of the } \\
\text { Bones and Joints of the Human Body, } \\
\text { preceder by some Observations on the } \\
\text { Influence of the Brain and Nerves. }\end{array}$ \\
\hline 1821 & James Wilson. & 9 & $\begin{array}{l}\text { Lectures on the Structure and Physio- } \\
\text { logy of the Male Urinary and Genital } \\
\text { Organs of the Human Body and on } \\
\text { the Nature and Treatment of their } \\
\text { Diseases, } \dagger\end{array}$ \\
\hline 1829 & $\begin{array}{c}\text { George James } \\
\text { Guthrie. }\end{array}$ & 9 & $\begin{array}{l}\text { Anatomy of the Circulating System in } \\
\text { Man: History of its Development and } \\
\text { Comparison of the Different Stages } \\
\text { with the Permanent Structures in In- } \\
\text { ferior Animals. Functions of the Heart } \\
\text { and Arteries and Veins Injuries and } \\
\text { Diseases of the Vascular System in } \\
\text { Man and the Treatment of the Same. }\end{array}$ \\
\hline 1830 & $\begin{array}{l}\text { George James } \\
\text { Guthrie. }\end{array}$ & 9 & $\begin{array}{l}\text { On the Anatomy of the Humad Pelvis: } \\
\text { its Sexual and National Varieties; Com- } \\
\text { parison of it with the Pelvis in other } \\
\text { Animals. } \\
\text { On the Anatomy of the Human Urinary } \\
\text { and Sexual Organs, illustrated by } \\
\text { Observations of the Same Parts in the } \\
\text { Inferior Classes of Animals. } \\
\text { On Wounds and Injuries of the Head } \\
\text { and Chest. } \\
\text { On the Diseases of the Urinary and } \\
\text { Sexual Organs, and more especially of } \\
\text { Diseases of the Urethra. }\end{array}$ \\
\hline 1831 & $\begin{array}{l}\text { George James } \\
\text { Guthrie. }\end{array}$ & 3 & $\begin{array}{l}\text { On the Anatomy of the Parts concerned } \\
\text { in Hernia. }{ }^{+}\end{array}$ \\
\hline 1832 & $\begin{array}{l}\text { George James } \\
\text { Gutbrie. }\end{array}$ & 9 & $\begin{array}{l}\text { Anatomy of the Organ of Vision in Man, } \\
\text { illustrated by Observations on its } \\
\text { Structure in the Lower Animals. } \\
\text { On the Diseases of the Eye and its Appen- } \\
\text { dages and the Treatment of the Same. }\end{array}$ \\
\hline 3833 & Henry Earle. & 9 & $\begin{array}{l}\text { On the Minute Anatomy and Phvsiology } \\
\text { of the Urinary Organs. On the Diseases } \\
\text { of the Same and their Treatment. } \\
\text { On the Anatomy of the Colon, and the } \\
\text { Nature and Treatment of Some of the } \\
\text { Diseases of that Intestine. } \$\end{array}$ \\
\hline
\end{tabular}

* Wilson completed this course in his Arris and Gale Lectures of this year.

Wilson, who died in this year, had arranged for a further course on The Brain and Nervous System.

${ }_{t}$ This course of lectures proceeded amidst much disturbance until the fourth lecture, when they were wholly interrupted by a systematic and continued riot. The lectures were consequently suspended and the theatre closed by the advice of the law officers of the College and by the concurrence of the trustees of the Museum until the sanction of the Cbancellor and judges had been obtained to a by law enabling the President and Council to repress any similar disturbances in future. $\$$ Earle continued this course in the Arris and Gale Lectures of the same year. is to give publicity to the accompanying amplifications and corrections of my pamphlet. Many of them I owe to $\mathrm{Mr}$. D'Arcy Power; upon others I have chanced in a research into the history of the College. As the "list" is given away, not sold, to anyone interested in medical history it is not likely that it will see a second edition.

I am, Sirs, yours faithfully,

VICTOR G. PLARR,

Librarian of the College.

The Library,:Royal College of Surgeons of Librarian of the College.

\section{THE SOUTH AFRICAN COMMISSION.}

\section{To the Editors of THE LANCET.}

SIRs,-As in the Crimea and in Egypt, so now in South Africa, war on a large scale seems to have as its invariable sequel accusations of peglect of sick and wounded involving mainly the Army Medical Department as responsible for the results, the conclusions of committees being hitherto impotent in the prevention of repetition of charges or of the conditions complained of. Another inquiry is in progress and it is a matter of profound importance to the accused department (for this is clearly the position of the Royal Army Medical Corps) that the proposed Commission should be so constituted as to contain within itself the means of eliciting the truth and the whole truth, and the requisite capacity to recognise and gauge the real import of the evidence; and from the facts adduced to fix the responsibility for shortcomings on the right shoulders and make proposals likely to prevent a recurrence in the future. Now, Sirs, when we note the tone of some of the debates in the House of Commons, the vacillation of the Government and the views expressed in the lay journals, I venture to think that to anyone bearing in mind the experience of the past and cognisant of army life, the duties of the Royal Army Medical Corps and the conditions under which its work has to be done in peace and in war, a feeling of grave scepticism will arise as to whether this Commission as proposed will be any more fruitful in results than its predecessors.

The original scope of the Commission as formulated by the Government was "to report as to the arrangements for the care and treatment of the sick and wounded during the campaign in South Africa" and to inquire especially into the complaints of negligence in regard to enteric fever; and to this end the Commission was constituted of three membersone judge and two medical men. And in riew of the fact that the subjects embraced by it are mainly professional, requiring not merely "common sense," but a specially trained technical sense for their solution, the commission was one fairly capable of doing the duty entrusted to it. $\mathrm{Mr}$. Balfour spoke of it as having "great qualities of knowledge and impartiality stamped upon it," and the Leader of the Opposition considered the medical members are "high-minded, straightforward men who will do their work well." Yet what do we find but the Government departing from their scheme, to which we must assume they had given reasonable thought, and agreeing to add two more members, neither of whom can have the necessary knowledge to guide them in such a professional inquiry, the numerical deciding power being now in the hands of those untrained to gauge the true import of the evidence and facts adduced! Moreover, the main objection to the original commission apparently was "that the inquiry would practically be in the bands of medical men," the view being held by some that medical men could not be relied on to act fairly in matters in which their fellow professionals were. concerned, they presumably being deficient in that sense of justice and rectitude of purpose allowed to most men; and these are points which the profession would do well to lay to heart.

Further it would appear that the inquiry is to be extended to transport, \&c. In the words of the leading Conservative journal, "the whole question of hospital administration at the seat of war and the general organisation and methods of the Royal Army Medical Corps will be thoroughly examined." And when cognisance is taken of this expansion the doubt still more is increased as to whether the Commission as proposed has the necessary capacity for the duties with which it is charged. In addition to what has been aforesaid, who among its members have that experience of war and that practical knowledge of the rules and regulations of the Service and the nature and work of the Royal Army Medical Corps and the conditions under which it is done as will entitle them to speak with authority on the matters to be inquired into? 
Mr. Balfour himself expressed the possibility of the danger of unfairness to the army medical officers from the medical members owing to the former "carrying ont their duties under.conditions not very familiar to doctors and surgeons at home"-a danger augmented with a majority with everything to learn. And when we note the remarks of $\mathrm{Mr}$. Burdett-Coutts apropos of himself we further recognise the possibility of injustice accruing either to the Department or to individaal members. He is recorded to have said that in his grave indictment of the medical arrangements in South Africa he was originally in a position of a plaintiff, but now in that of a defendant of the great interest involved in the truth or untruth of his statement; and, going on to say that now the Government would call him as a witness to enable him to state his case with possibly the opportunity of producing other witnesses, he asks: "Was that enough in this case? What was the usual practice when a man was placed in his position? Had he not a right to put what questions he liked, to cross-examine the witnesses?"-questions which elicited cheers. Now it is apparent that the Department is the true defendant in this inquiry, and its position is exactly that which Mr. Burdett. Coutts details as characterising himself ; and if these essentials to justice are requisite in the one instance why not in the other? Oan it for a moment be said that the proposed Commission will contain within itself these essentials? What might go far towards placing it in a position to do for the Department what it cannot do for itself would be to add to it one or two independent army medical officers whose knowledge and experience would tend towards eliciting, the whole truth and giving proper weight and importance to the facts adduced.

Well, Sirs, I take it for granted that the view of the Department is that neither in the Crimean nor in the Egyptian inquiry was justice meted out to it, and the possibility of a like fate befalling it in this instance bas to be faced; not, of course, from set purpose, but from inability on the part of a Commission as proposed to decide on technical points and disentangle and rightly apportion its true responsibility among the more powerful army sections (including, of course, the War Office) which are also involved in this important and difficult inquiry. What does the country really want-a "scapegoat" for the relief of its feelings with a lapse into the old ways, as formerly, as soon as the excitement of war has passed away? Or is it for once thoroughly determined that the experience and teaching of the past shall not be lost, but shall bear such fruit as to make a recurrence of such departmental complaints an impossibility in the future? Have we solid grounds for such a hope?

I am, Sirs, yours faithfully,

FraxCIS H. WELCH, F.R.C.S. Eng. Surgeon-Colonel (retired), A.M.S.

Branđram-road, Lee, S.E., July 9th, 1900.

\section{"THE CAUSE OF CARIES OF THE TEETH."}

To the Editors of THE LANCET.

SIRS,-Dr. J. Sim Wallace holds that the great prevalence of dental caries among civilised peoples is due to their eating soft and papny foods requiring little mastication. Some years ago you were good enough to publish in THE LANCET a letter from me in which I urged the same view. My interest in the subject led me to read Dr. Wallace's work carefully directly it appeared, and I hope I may be permitted to say that $I$ was greatly impressed by the closeness of his arguments and the scientific spirit pervading his book.

My original contention was that soft foods predispose to caries by leading to imperfect mastication and thus to defective nutrition and development of the teeth; and although I still venture to think that this may be a factor Dr. Wallace has converted me to his view that soft foods lead to caries essentially by modifying the buccal environment of the teeth-the teeth being no longer properly cleansed by coarse fibrous foods, the buccal secretions being no longer adequately excited, and so forth.

Regarding Dr. Wallace's remarks as to the tooth-brush not being altogether an unmixed blessing, it is significant that the very next day after reading them there consulted me a man, aged 22 years, who had never in his life used a toothbrush, and he had 32 sound teeth in his head.

I feel convinced that if Dr. Wallace's views are taken to heart by the medical profession we shall do much to diminish caries and other defects of the teeth. I, indeed, believe with him that we have it in our power to rear a race having teeth every bit as good as those of our primitive ancestors.

May I take this opportunity of saying that there is, in my opinion, a further indictment to be made against the use of soft food. I believe we have in the imperfect mastication which foods of this kind lead to a clue to the long soughtfor patkology of adenoids a subject with which I am dealing fully elsewhere.

I am, Sirs, yours faithfully,

Wimpole-strett, W., July 9tb, 1960. HARRY CAMPBELL.

\section{To the Editors of THE LANCET.}

Sirs, - The cause of caries of the teeth must be one of uni. versal distribution and $\mathrm{I}$ have for years expressed my opinion that it is the universal consumption of bread made from flour deprived almost entirely of " earthy matter" ; every particle of bran, which contains nearly all the above, being removed therefrom, the motber's blood therefore is deficient in the constituents necessary to properly build up and consolidate the bones and teeth of the foetus. Fvery generation will, I fear, get worse and worse unless something can be done to improve the character of the bread consumed. Now I am writing may $I$ be allowed to say that I have met with two cases in which mothers have vaccinated themselves accidentally from their babes; it is, therefore, I should think, not so very uncommon. I am, Sirs, yours faithfully,

Donington, Spalding, July 10th, 1950. E. W. JOLLYE.

\section{"A PLEA FOR EARLY OPERATION IN CASES OF UNDOUBTED TUBERCLE OF THE LUNG."}

To the Editors of THE LANCET.

SIRS,-The recent article in THE LANCET written by Mr. Foster Palmer on "A Plea for Early Operation in Cases of Undoubted Tubercle of the Lung" reminds me of a paper that I wrote some years ago but did not publish. By early operation I suppose the writer means such to attempt a radical cure, and not a palliative measure such as incision and drainage of advanced phthisis with pleural adhesions. None of the present procedur $\epsilon$ are well adapted for a radical excision, and such is rarely attempted, the fears of pneumothorax and hæmothorax deterring the surgeon from operating. But in the course of every lung case there must happen a time when, though the chance of medical cure is past, there still exists a time for radical excision before it advances too far. Let us take a case of a young person with phthisis in the apex of one lung which has gone on to cavity formation and in which there are as yet no pleural adhesions. If excision be desired how shall we proceed? In the article referred to the procedures are as follows. 1. To sew the pulmonary pleura to the costal pleura beyond the seat of the disease before operating. In such a case as the above this would be impossible. It would do in a case of large cavities with no pleural adhesions and some reasons against excision, such as the other lung affected, and then would only be as a preliminary to incising and draining. 2. To trust to previous existence of adhesions. This is not the case as above and if present would prevent a radical excision. 3. To excite artificial adbesions. This is dangerous, uncertain, and leaves a pathological lesion and a breeding-place for tubercle behind in a tuberculous subject. 4. Artificial inflation. This is unsatisfactory and the moving lung would hinder the operation. The method which I proposed was to collapse the lung artificially on the affected side by passing into the pleural cavity a suitable medium such as sterilised air, or preferably sterilised water or a weak antiseptic solution. This treatment is commenced some days before opening the chest and may be done by placing a small tube in one of the lower intercostal spaces and opening into the pleural cavity and fitted with tubing and stopcocks. The medium is passed in certain quantities daily and gradually, till the lung is suffciently collapsed, and completed on the day of operation, the patient being thus slowly accustomed to using only one lung and being spared any sudden collapse. Now the pleural cavity can be opened as safely as a peritoneal cavity, due care being taken in the technique of the operation.

As regards the operation itself I suggest, first, a fiap comprising all the tissues down to the costal surface of the costal pleura, and this being well demonstrated and all bæmorrhage 